\title{
Self-Compacting Concrete: A Review
}

\section{Gomasa Ramesh}

\begin{abstract}
Self-compacting Concrete is one of the new innovative types of concrete, and it is used widely in the construction of several industries. This type of concrete can be made by using different admixtures and their combinations. The main aim of the SCC is to improve the durability of the concrete structure and also improves the workability of the concrete structure. Nowadays construction of large structures, it isn't easy to compact the reinforced concrete without voids. This can be overcome by using self-compacting concrete. This type of concrete does not require compaction. So, it is one of the significant advantages of the concrete structure and saves time and energy. This Review paper explains self-compacting concrete and its advantages and uses, and applications of SCC. This paper helps to an understanding about self-compacting concrete.

Keywords: Self-compacting Concrete, Workability, Excellent Durability, Admixtures, Mix design, Manufacturing, Mechanical Properties.
\end{abstract}

\section{INTRODUCTION}

Self-Compacting Concrete is a special type of concrete used in all civil engineering and structural engineering works. It is one of the important types of innovative concrete, and it has excellent properties. It was first used at the end of the $19^{\text {th }}$ century. Okamura introduces this type of concrete. This type of concrete is also known as self-consolidating concrete. One of the most important properties of this type of concrete does not require vibration or compaction. This type of concrete is flowing very easily. This type of concrete has not required more Water than compared with conventional concrete. This type of concrete is similar to the normal conventional concrete in setting and curing and mechanical properties. Normal conventional concrete is dense and viscous, but SCC is not like moderate viscosity compared to conventional concrete. This type of concrete is first used in Japan and North America, and later it is used worldwide. SCC is a fresh concrete, and it flows under its weight, and it does not require compaction.

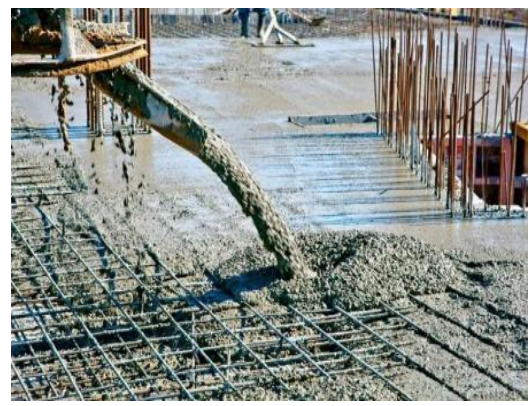

\footnotetext{
Manuscript received on 04 October 2021 | Revised Manuscript received on 27 October 2021 | Manuscript Accepted on 15 November 2021 | Manuscript published on 30 November 2021. * Correspondence Author

Gomasa Ramesh*, M.Tech, Structural Engineering, Vaagdevi college of Engineering, Warangal, 506005, Telangana, India EMail:rameshgomasa1@gmail.com

(C) The Authors. Published by Lattice Science Publication (LSP). This is an open access article under the CC-BY-NC-ND license (http://creativecommons.org/licenses/by-nc-nd/4.0/)
}

\section{LITERATURE REVIEW}

\section{Arulsivanatham 2017 et al.}

This research paper author explained the history of the self-compacting concrete and mechanical properties of SCC and materials used for SCC and explained mix design for SCC. The author also explained factors affecting selfcompacting concrete and properties of fresh SC concrete. The author also explained fresh workability criteria for SC concrete, and the author explained the hardened properties of the SC concrete.

\section{Parvin 2013 et al.}

This Research Paper Author explains the physical requirements of self-compacting concrete and SC concrete making materials for construction. This author also explained the mixed design approach for self-compacting concrete and test methods on SC concrete. The author also explained on different properties are used in the selfcompacting concrete and their mix design.

\section{METHODOLOGY}

Self-compacting concrete can be compacted into every corner of the formwork easily. Hence it is also called highly engineered concrete. This type of concrete has higher fluidity. The main problem of concrete is durability issues, which can be overcome by using self-compacting concrete. This is the main reason for the development of selfcompacting concrete by Okamura in Japan.

\section{OBJECTIVES \& USES}

- Economical

- Constructability is good

- Construction is faster

- Homogeneity

- Improve durability

- $\quad$ Structural integrity improved

- Segregation resistance is good

- Yield stress is low

- The cost of compaction is less

- Easy to place

- Reduce wear

- Do not require vibrators

- The surface finish is good

- Minimize voids

- $\quad$ Easier pumping

- Deformability is high

- Viscosity is moderate

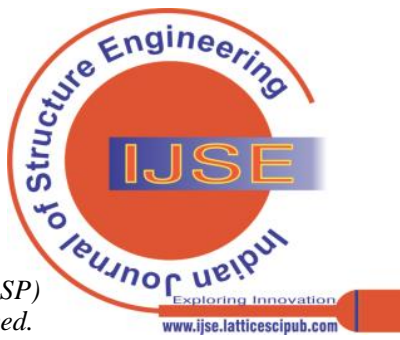


- $\quad$ Fewer labours required

- Low Water required

- Low cost

- Less require human resources

\section{DIS ADVANTAGES}

- $\quad$ Problem with creep

- Shrinkage

- $\quad$ Difficult to mix design \& complicated

- Requires more trials

- Costlier

\section{MATERIALS USED}

- Fine aggregate: well-graded aggregates such as cubical or rounded aggregates are used in the SCC.

- Cement: OPC 43 or 53 grade of cement is generally used in the SCC.

- Coarse aggregate: it is also similar to the above aggregates.

- Admixtures: In this type of concrete, there are two types of admixtures used. One is mineral admixture (fly ash- it increases the quality and durability of SCC concrete, silica fume- it is used to improve the various mechanical properties of the SCC concrete and GGBS it is used to improves the rheological properties of the SCC concrete). Another one is chemical admixtures (superplasticizers and airentraining agents etc.).

- Water: normal distilled Water is used similar to conventional concrete.

\begin{tabular}{|c|c|c|}
\hline $\begin{array}{c}\text { ORDINARY } \\
\text { CONCRETE }\end{array}$ & & SCC \\
\hline GRAVEL & & GRAVEL \\
\cline { 1 - 1 } SAND & Sagregate & SAND \\
\hline CEMENT & $\begin{array}{c}\text { Binding } \\
\text { material }\end{array}$ & $\begin{array}{c}\text { CEMENT + CHEMICAL } \\
\text { ADMIXTURES }\end{array}$ \\
\hline $\begin{array}{c}\text { WATER } \\
\text { (+ PLASTICIZER) }\end{array}$ & Fluid & $\begin{array}{c}\text { WATER } \\
\text { SUPER PLASTICIZER } \\
\text { THICKENER }\end{array}$ \\
\hline
\end{tabular}

\section{Properties of SCC}

In this, there are three important properties for SCC. The first one is the ability to fill- this is also called the filling ability. The second one is ability of passing- this is also called passing ability, and the last one is resistance to Segregation.

- Filling Ability: In this property of the concrete flows easily at a certain speed in the formwork.

- Passing Ability: In this property, concrete is passing safely and easily into reinforcement without any troubles. So, the passing of material into the steel or reinforcement is very easy compared to the normal conventional concrete.

- Segregation Resistance: In this, aggregates are homogeneously distributed along with horizontal and vertical directions.

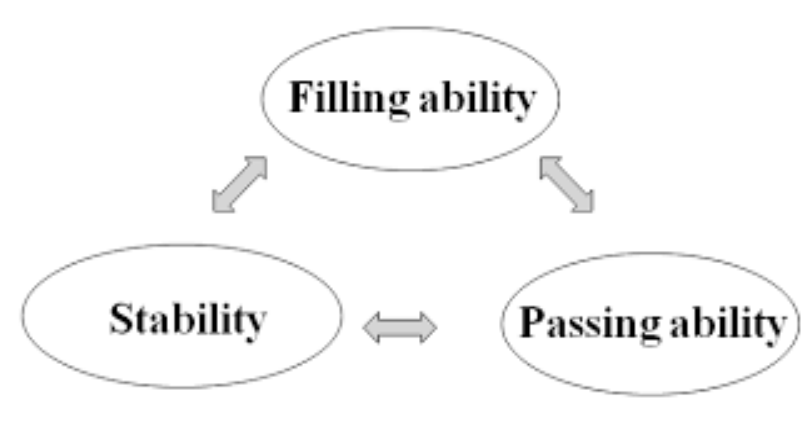

\section{Manufacturing and Production}

In this, proportions of the concrete are taken utilizing volume rather than the mass of concrete. So, aggregates are all taken from the same source only, i.e., source of aggregates is the same for all. After that, mixing can be done for a longer time than the standard conventional concrete. After the mixing of concrete, placing can be done with the help of types of equipment. In this, after the placing, curing can be done similar to conventional concrete.

\section{Mix Design}

In this mix design of concrete, a sequential order can be followed for self-compacting concrete. In this first determine the following properties

- Air content- in this air content used around two percentage.

- The volume of coarse aggregate- should below

- Content of sand- low

- Mixing Composition- good

- Amount of Admixture- more

- Water powder ratio- low

\section{APPLICATIONS}

- Used for repair and rehabilitation of structures

- Used for retaining walls for highly durable and stable

- Used for construction pile foundations

- Used in the construction of raft foundation

- Used for complicated structures with steel

- Used in areas of pipes and conduits

- Columns

- Drilled shafts

\section{TESTS \& RESULTS}

There are different types of tests used on selfcompacting concrete to test its durability and performance. In this one of an important type of tests are as follows;

Slump flow test: it is the one of important test on selfcompacting concrete. This test is used to know the horizontal flow of the concrete. It is used to know the filling capacity or ability of the concrete. This type of test can be performed in the field.

Published By:

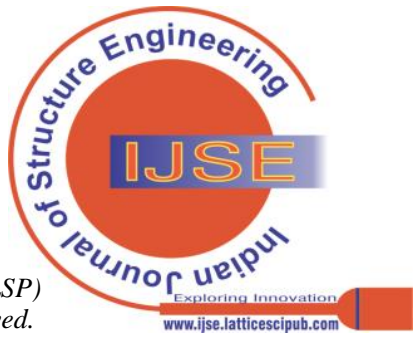




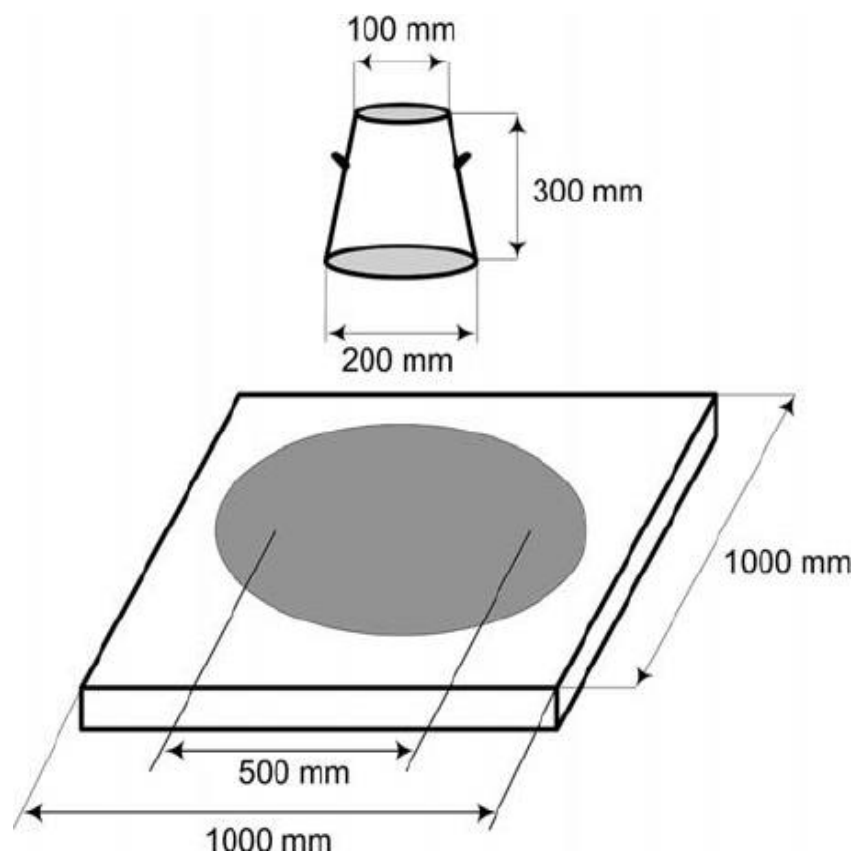

L box test: this type of test is used to determine the passing ability of the concrete. Around 14-15 litres of concrete can be filled into the vertical section of the $\mathrm{L}$ Box. This test can be completed within five minutes for better results. Calculate the blocking ratio $\mathrm{H} 2 / \mathrm{H} 1$.

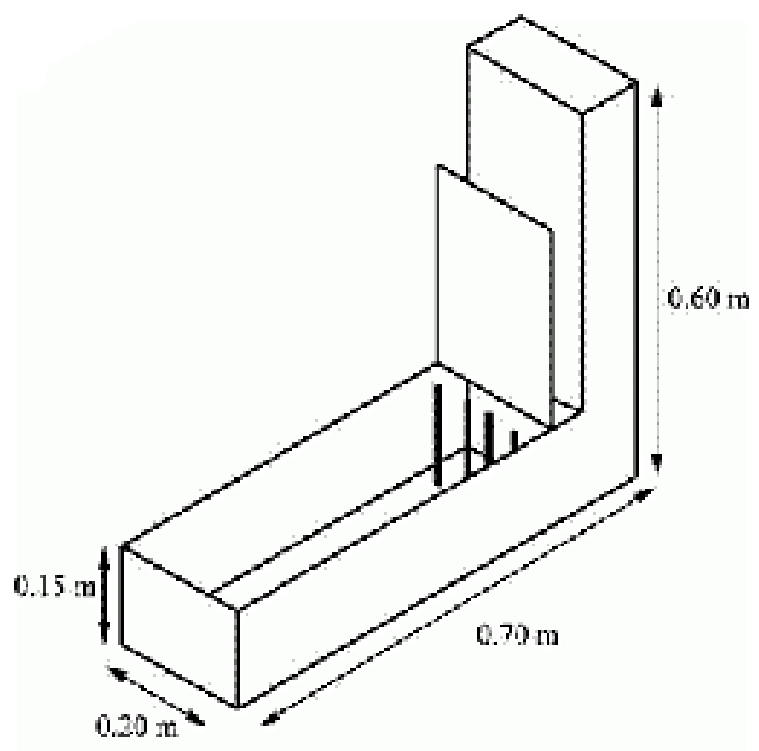

U box test: this type of test is also used to calculate the concrete's passing ability. In this test, around twenty litres of concrete are taken into the U Box. In this, there are two compartments in the $\mathrm{U}$ Box. The first compartment height is measured (H1), and the second compartment of the $U$ Box measured height is (H2). The complete process of this test can be complete within five minutes only. The filling height of this test is $\mathrm{H} 1-\mathrm{H} 2$. If the value of $\mathrm{H} 1-\mathrm{H} 2$ equals zero, then the concrete passing ability is good and which is flows like Water and the filling height is not more than $30 \mathrm{~mm}$.

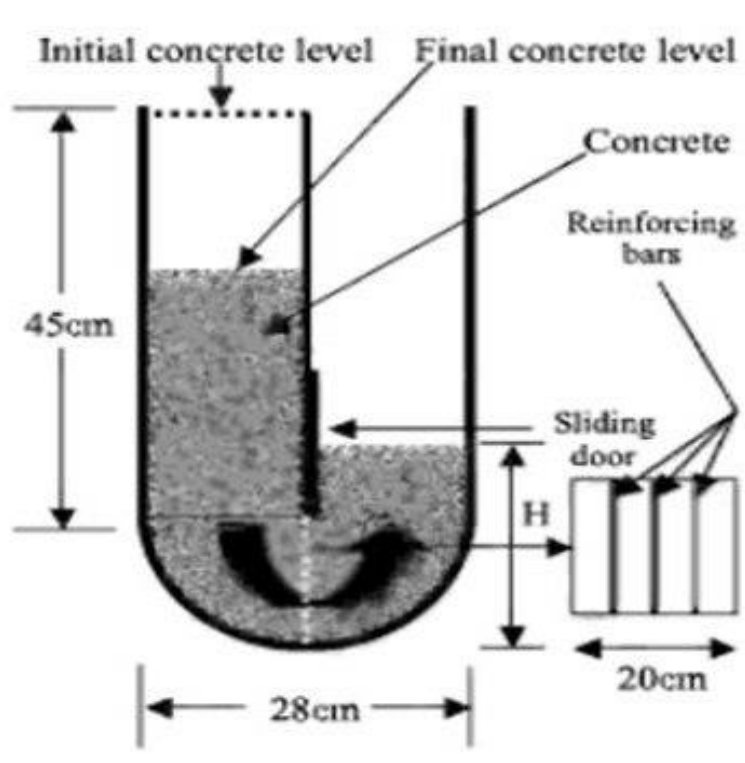

V funnel test: this type of test is conducted to know the filling ability of the concrete. This size of aggregates is used around $20 \mathrm{~mm}$. this test is also used to determine the segregation resistance.

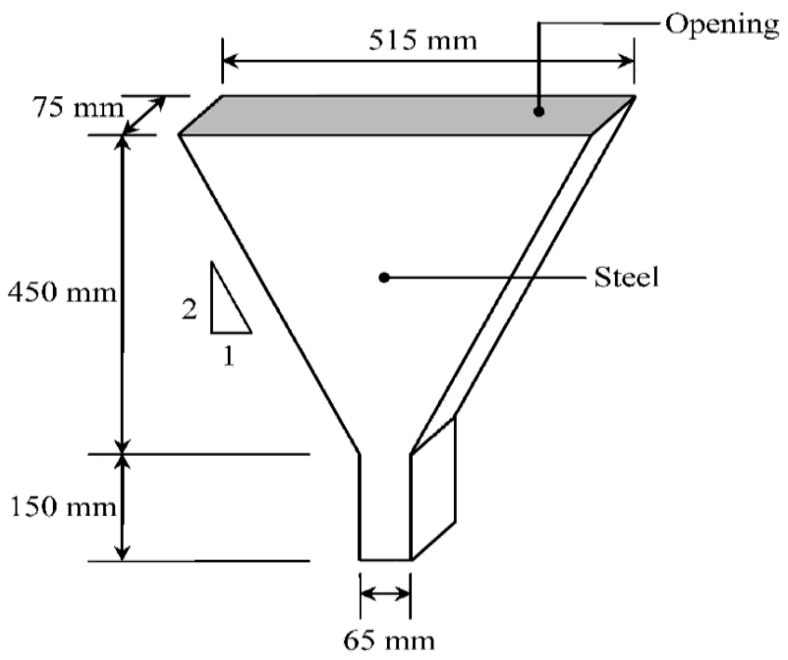

GTM screen stability test: this type of test is used for segregation resistance of concrete.

Orimet test: this is also one of the filling abilities tests of concrete.

\section{CONCLUSION}

Self-compacting concrete is an excellent material for the construction of any structures. There are many advantages and applications are there for using SCC rather than conventional concrete. It is also one of the finest good building materials for the construction of structures. The compaction amount depends on type of concrete; by using this no, there is no need for Some are disadvantages are also but develop a good SCC according to IS Codes to improve the concrete's workability. The main conclusion of using the self-compacting concrete is as follows;

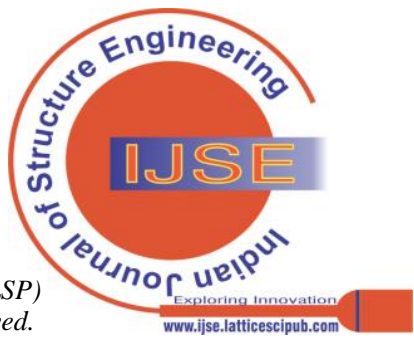


- $\quad$ Save time

- $\quad$ Save cost

- Increase durability

- Safe working environment

- The cost of SCC is higher than conventional concrete, about $10-15 \%$.

\section{REFERENCES}

1. Arulsivanatham 2017 et al., "A Review on Self Compacting Concrete", International Journal of ChemTech Research, Vol.10 No.11, pp 62-68.

2. Parveen 2013 et al., "Self-compacting concrete", international conference on trends and challenges in concrete structures.

3. Gomasa Ramesh, Dr. Annamalai Rangasamy Prakash, "Repair, Rehabilitation and Retrofitting of Reinforced Concrete Structures," Special Issue 2021, International Journal of Engineering Research \& Technology (IJERT) ISSN: 2278-0181 Published by, www.ijert.org NCACE - 2020 Conference Proceedings.

4. Srinath, Doddipati, et al. "Mechanical properties of sustainable concrete by using RHA and hydrated lime." Materials Today: Proceedings (2021). [CrossRef]

5. Dharna Ramya, Gomasa Ramesh and Dr. Annamalai Rangasamy Prakash, "Shear Behavior of Hybrid Fiber Reinforced Concrete", International Journal for Modern Trends in Science and Technology, Vol. 07, Issue 02, February 2021, pp.-79-82, DOI:10.46501/IJMTST0702013

6. Gomasa Ramesh, Dharna Ramya, Mandala Sheshu Kumar; "Health Monitoring of Structures by Using Non-Destructive Testing Methods", International Journal of Advances in Engineering and Management (IJAEM) Volume 2, Issue 2, pp: 652-654, DOI:10.35629/5252-45122323

7. Ramya, Dharna, et al. "Shear Behavior of Hybrid Fiber Reinforced Concrete." Concrete", International 7.02 (2021): 79-82. [CrossRef]

8. Doddipati Srinath, Gomasa Ramesh, "Mechanical Properties of Sustainable Concrete by using RHA and Hydrated Lime", International Journal for Modern Trends in Science and Technology, Vol. 07, Issue 02, February 2021, pp.-83-86, DOI:10.46501/IJMTST0702014 [CrossRef]

9. Ramesh, Gomasa, et al. "Repair, rehabilitation and retrofitting of reinforced concrete structures by using non-destructive testing methods." Materials Today: Proceedings (2021). [CrossRef]

10. Gopu Anil, Gomasa Ramesh and Dr. Annamalai Rangasamy Prakash, "An Experimental Study Investigation on Self Compacting Concrete and Strength Properties by using Fiber Reinforcement", International Journal for Modern Trends in Science and Technology, Vol. 07, Issue 02, February 2021, pp.-93-96, DOI: 10.46501/IJMTST07022016

11. Krishna, Bonagani Vamshi, et al. "Effect of Geo-Activator on Strength and Durability Properties of Geopolymer Concrete." (2021).

12. Sriramoju Sravani, Gomasa Ramesh and Dr. G. Dinesh Kumar, "Study on Percentage Replacement of Cement by Glass powder for M20 Grade Concrete", International Journal for Modern Trends in Science and Technology, Vol. 07, Issue 02, February 2021, pp: 129132, DOI:10.46501/IJMTST0702022

13. Bandi Pooja, Gomasa Ramesh and Dr. G. Dinesh Kumar, "Experimental Study on Mechanical Properties of Geopolymer Concrete by using Fly Ash and RHA", International Journal for Modern Trends in Science and Technology, Vol. 07, Issue 02, February 2021, pp.-50-55, DOI:10.46501/IJMTST0702008

14. Palakurthi Manoj Kumar, Gomasa Ramesh and Dr. Annamalai Rangasamy Prakash, "Evaluation of Different Tests and their Comparisons by Combining Cement with Various Binders," International Journal for Modern Trends in Science and Technology, Vol. 07, Issue 03, March 2021, pp.: 119-122, DOI: 10.46501/IJMTST0703021

15. Bonagani Vamshi Krishna, Gomasa Ramesh and Dr. Annamalai Rangasamy Prakash, "Effect of Geo-Activator on Strength and Durability Properties of Geopolymer Concrete," International Journal for Modern Trends in Science and Technology, Vol. 07, Issue 03, March 2021, pp.: 123-126, DOI:10.46501/IJMTST0703022

16. Gomasa Ramesh, Doddipati Srinath, Mandala Sheshu Kumar; "Earthquake Resistant of RCC Structures" Published in International Journal of Trend in Scientific Research and Development (ijtsrd), ISSN: 2456-6470, Volume-4, Issue-5, August 2020, pp.808-811.

17. Gomasa Ramesh, Doddipati Srinath, Mandala Sheshu Kumar, "Importance of Dynamic Analysis for RCC Structures," International
Journal for Modern Trends in Science and Technology, 6(8): 271276, 2020, DOI:10.46501/IJMTST060844 [CrossRef]

18. Gomasa Ramesh, D Srinath, "Repair, rehabilitation and retrofitting of reinforced concrete structures by using non-destructive testing methods," March 2021, Materials Today: Proceedings, DOI: 10.1016/j.matpr.2021.02.778 [CrossRef]

19. D Srinath, G Ramesh, "Mechanical properties of sustainable concrete by using RHA and hydrated lime," March 2021, Materials Today: Proceedings, DOI: 10.1016/j.matpr.2021.02.785 [CrossRef]

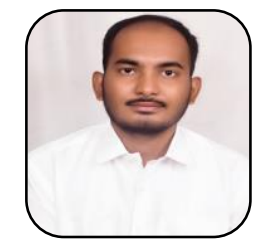

\section{AUTHORS PROFILE}

Mr. Gomasa Ramesh, B. Tech Civil Engineering, M. Tech Structural Engineering, Vaagdevi College of Engineering, Warangal, 506005, Telangana, India. Presented and participated in various International conferences and National Conferences and received Best Paper Awards for some Papers and received Best Young Researcher Award for 2020. Published more than 15+ Research Papers in International Peer-Reviewed UGC Journals. Received Academic Excellence Awards from Andhra Pradesh Social Welfare Residential School, Manthani during SSC-2011(School First) and also Received Academic Excellence Award from VMR Polytechnic, Diploma in Civil Engineering during 2014 (Class First) and also Received Academic Excellence Award from HITS, Hyderabad during 2017 (Class Second). Selected and Shortlisted for Site Engineer Position to Work with GHMC Housing Board of Telangana (Application Id:14517. Member of various Professional Bodies American Society of Civil Engineers, Structural Engineering Institute, Institute of Structural Engineering, American Concrete Institute and American Society of Testing Materials etc. 